\author{
M.M. Bukenov, A.A. Adamov, Y.M. Mukhametov \\ L.N. Gumilyov Eurasian National University, Nur-Sultan, Kazakhstan \\ (E-mail: eldos_sports@mail.ru)
}

\title{
Two-dimensional thermo-viscoelastic waves in layered media
}

\begin{abstract}
Dynamic problems of deformation of solids have been the subject of numerous studies in the CIS and abroad. The rejection of a number of simplifying assumptions made in the cited and other published works leads to the need for further refinement and improvement of mechanical and mathematical models describing the kinematics and stress state of both the drummer and the barrier. Further, the axisymmetric collision of a cylindrical indenter with an obstacle in the form of a package of isotropic plates containing free cavities and rigid inclusions is numerically investigated within the framework of the coupled theory of thermoviscoelasticity. Various formulations of the problems of the theory of elasticity and thermo-viscoelasticity are possible. However, the used formulation in velocities and stresses is one of the most universal, since it allows solving the main boundary value problems (including mixed ones) by a uniform way. The paper gives a grid-characteristic scheme and its convergence. In accordance with the theory of A.A. Samarskii, the stability in the energy norm of the grid problem is proved.
\end{abstract}

Keywords: two-dimensional thermo-viscoelastic waves, stability of a difference scheme, convergence of a solution of a difference problem, indenter, deformation, tensor, stresses.

\section{Introduction}

Let a deformable continuous (or hollow) cylinder of finite length $h_{0}$ as $t<0$ simultaneously performs translational (with velocity $V_{0}$ ) and rotational (with angular velocity $\omega_{0}$ ) motion. At the initial moment of time $t=0$, the rotating indenter with its flat base normally collides with the surface of a multilayer plate (barrier) weakened by cylindrical cavities and inclusions.

To describe the dynamic behavior of an isotropic medium, we use the relations

$$
\dot{\sigma}+\frac{\sigma}{\theta_{1}}=3 K(\dot{\varepsilon}+3 \alpha \stackrel{\bullet}{\mathrm{T}}) ; \dot{S}_{i j}+\frac{S}{\theta_{2}}=2 \mu \dot{e_{i j}}
$$

where $\sigma$ - is the sum of normal voltages; $\varepsilon$ - volumetric deformation; $S_{i j}, e_{i j}-$ components of deviators of symmetric stress and strain tensors; $\mathrm{T}$ - temperature increment; $\mathrm{K}=\lambda+\frac{2}{3} \mu$ - elastic modulus of bulk expansion - compression $\left(\lambda, \mu\right.$ - Lame parameters); $\alpha$ - linear thermal expansion coefficient; $\theta_{1}, \theta_{2}$ - relaxation times for ball and deviatoric stresses; a dot above the letters means time differentiation.

Under the conditions of axial symmetry, the written system, which is supplemented by three equations of motion and the equation of heat conduction, is equivalent to the following dependencies, containing, as unknown displacement velocities, stresses and temperatures:

$$
\begin{gathered}
\rho \dot{u}=\frac{\partial \sigma_{r}}{\partial r}+\frac{\partial r_{r z}}{\partial z}+\frac{\sigma_{r}-\sigma_{\varphi}}{r} ; \\
\rho \dot{\vartheta}=\frac{\partial \sigma_{r z}}{\partial r}+\frac{\partial r_{z}}{\partial z}+\frac{\sigma_{r z}}{r} ; \\
\rho \dot{w}=\frac{\partial \sigma_{r \varphi}}{\partial r}+\frac{\partial r_{z \varphi}}{\partial z}+\frac{2 \sigma_{r \varphi}}{r} ; \\
\dot{\sigma}_{r}+\eta \sigma_{r}-\beta \sigma=\lambda \dot{\varepsilon}+2 \mu \dot{\varepsilon}_{r}-p \dot{\mathrm{T}} ; s \\
\dot{\sigma}_{\varphi}+\eta \sigma_{\varphi}-\beta \sigma=\lambda \dot{\varepsilon}+2 \mu \dot{\varepsilon}_{\varphi}-p \dot{\mathrm{T}} ; \\
\dot{\sigma}_{z}+\eta \sigma_{z}-\beta \sigma=\lambda \dot{\varepsilon}+2 \mu \dot{\varepsilon}_{z}-p \dot{\mathrm{T}} ;
\end{gathered}
$$




$$
\begin{aligned}
\sigma_{r \varphi}^{\bullet}+\eta \sigma_{r \varphi} & =2 \mu \varepsilon_{r \varphi}^{\bullet} ; \sigma_{z \varphi}^{\bullet}+\eta \sigma_{z \varphi}=2 \mu \varepsilon_{z \varphi}^{\bullet} ; \sigma_{r z}+\eta \sigma_{r z}=2 \mu \varepsilon_{r z}^{\bullet} \\
c \dot{\mathrm{T}} & =\mathrm{K}\left(\frac{\partial^{2} \mathrm{~T}}{\partial r^{2}}+\frac{1}{r} \frac{\partial \mathrm{T}}{\partial r}+\frac{\partial^{2} \mathrm{~T}}{\partial z^{2}}\right)-p \mathrm{~T} \dot{\varepsilon}+W^{*}
\end{aligned}
$$

where

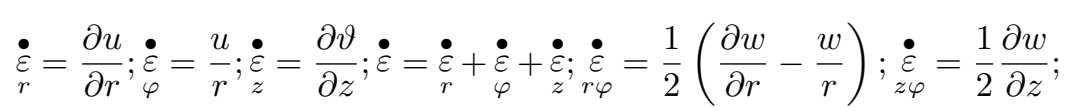

$$
\begin{aligned}
& \underset{r z}{\stackrel{\varepsilon}{r}}=\frac{1}{2}\left(\frac{\partial \vartheta}{\partial r}+\frac{\partial u}{\partial z}\right) ; \sigma=\sigma_{r}+\sigma_{\varphi}+\sigma_{z} ; \eta=\frac{1}{\theta_{2}} ; \beta=\frac{1}{3}\left(\frac{1}{\theta_{2}}-\frac{1}{\theta_{1}}\right) ; p=3 \mathrm{~K} \alpha \\
& W^{*}=\frac{1}{2 \mu \theta_{2}} s_{i j} s_{i j}+\frac{\sigma^{2}}{9 \mathrm{~K} \theta_{1}} ; s_{i j} s_{i j}=s_{r}^{2}+s_{\varphi}^{2}+s_{z}^{2}+2\left(\sigma_{r \varphi}^{2}+\sigma_{z \varphi}^{2}+\sigma_{r z}^{2}\right) ; s_{r}=\sigma_{r}-\frac{\sigma}{3} ; s_{\varphi}=\sigma_{\varphi}-\frac{\sigma}{3} ; \\
& s_{z}=\sigma_{z}-\frac{\sigma}{3} .
\end{aligned}
$$

Here $u, \vartheta, w$ are the components of the velocity vector in the direction of the coordinate axes: $r, z, \varphi, \sigma_{i j}$ are the stress components; $\rho$ is density; $\mathrm{K}$ is coefficient of thermal conductivity; $c$ is specific volumetric heat capacity with constant strain tensor; $p$ is parameter of connectivity of deformation fields and temperature; $W^{*}$ is the energy dissipation function [1], which takes a zero value for a perfectly elastic medium $(\eta=\beta=0)$. The connectivity equation is nonlinear due to the presence of a member $p \mathrm{~T} \dot{\varepsilon}$ in it. It should also be pointed out that the third, seventh and eighth equations form an independent system with respect to the quantities $w, \sigma_{r \varphi}, \sigma_{z \varphi}$.

Various formulations of the problems of the theory of elasticity and thermo-viscoelasticity are possible [2, 3]. However, the formulation used in velocities and voltages is one of the most universal, since it allows one to solve the main boundary problems (including mixed ones) in a uniform way. Among the first publications, where a similar form was proposed for writing the defining equations for a linearly elastic medium under plane strain conditions, the work [4] should be noted.

With a small thermal perturbation, the thermo-viscouselastic properties of the material can be considered being independent of temperature [5, 6]. In [5], for example, it was shown that when $\mathrm{T} \leq 390 \mathrm{~K}$ the value of the viscosity coefficient $\eta^{*}=2 \mu \theta_{2}$ for pure aluminum remains unchanged.

The boundary conditions for the considered contact problem are formulated as follows. The outer boundaries of the deformable mechanical system, as well as the walls of the internal cavities, are free from external forces: $\sigma_{z}=\sigma_{r z}=\sigma_{z \varphi}=0$ and $\sigma_{r}=\sigma_{r z}=\sigma_{r \varphi}=0$ (for boundaries that are parallel to the axis $r$ and $z$, respectively). If the region $r_{1}<r<r_{2}, z_{1}<z<z_{2}$ is a rigid inclusion with density $\rho_{*}$, then at the points of its boundaries

$$
\begin{gathered}
u=0 \\
\dot{\vartheta}=\frac{2 \pi}{\mathrm{M}_{*}}\left\{\int_{r_{1}}^{r_{2}}\left[\sigma_{2}\left(r, z_{2}\right)-\sigma_{z}\left(r, z_{1}\right)\right] r d r+\int_{z_{1}}^{z_{2}}\left[r_{2} \sigma_{r z}\left(r_{2}, z\right)-r_{1} \sigma_{r z}\left(r_{1}, z\right)\right] d z\right\} \\
\dot{w}=\frac{2 \pi r}{\mathrm{M}_{*}\left(r_{1}^{2}+r_{2}^{2}\right)}\left\{\int_{r_{1}}^{r_{2}}\left[\sigma_{z \varphi}\left(r, z_{2}\right)-\sigma_{z \varphi}\left(r, z_{1}\right)\right] r^{2} d r+\int_{z_{1}}^{z_{2}}\left[r_{2}^{2} \sigma_{r \varphi}\left(r_{2}, z\right)-r_{1}^{2} \sigma_{r \varphi}\left(r_{1}, z\right)\right] d z\right\} \\
\mathrm{M}_{*}=\pi\left(r_{2}^{2}-r_{1}^{2}\right)\left(z_{2}-z_{1}\right) \rho_{*} .
\end{gathered}
$$

It is easy to notice that with a sufficiently large inclusion density, located in the initially quiescent medium, $\vartheta \approx w \approx 0$.

On a circular platform, collisions $r_{0} \leq r \leq R, z=0$ can be performed as conditions for rigid coupling of the end face of the striker with the surface of the obstacle

$$
\begin{gathered}
{[u]=[\vartheta]=[w]=\left[\sigma_{z}\right]=\left[\sigma_{r z}\right]=\left[\sigma_{z \varphi}\right]=0 ;} \\
\{[u]=\lim u(z-0)-\lim u(z+0)\},
\end{gathered}
$$

and the boundary conditions that simulate the absence of friction forces between interacting bodies (smooth impact). In this case, the first and fifth equations in (5) are replaced by

$$
\sigma_{r z}=0
$$


If, in the course of a smooth stroke, the voltage $\sigma_{z}$ or $\sigma_{z \varphi}$ vanishes at any point of the contact zone, then the type of boundary conditions will change and thereafter, for this point, respectively, it is assumed $\sigma_{z}=0$ or $\sigma_{z \varphi}=0$.

On the flat boundaries of the compound of dissimilar materials that make up the layered package, the conditions of rigid adhesion are carried out (5).

It is assumed that the heat exchange of the mechanical system with the environment, the temperature of which is considered constant $\left(\mathrm{T}_{0}=\right.$ const), is carried out according to Newton's law with the nonlinear dependence of the heat transfer coefficient on temperature:

$$
-\mathrm{K}_{n} \frac{\partial \mathrm{T}_{n}}{\partial n}=\alpha_{s}\left(\mathrm{~T}_{n}-\mathrm{T}_{0}\right)
$$

where

$$
\alpha_{s}=0,23 \cdot 10^{-6} \xi\left(\frac{\mathrm{T}_{0}+\mathrm{T}_{n}}{2}\right)^{3}+1,4\left(\frac{\mathrm{T}_{n}+\mathrm{T}_{0}}{h_{0}}\right)^{\frac{1}{4}} \cdot\left(\frac{\mathrm{B} B}{m^{2} \mathrm{~K}}\right) .
$$

Here $\mathrm{T}_{0}$ is the surface temperature ( $n$ is the direction of the normal to the surface at the boundary points); $\xi$ is the degree of blackness of the body. The temperature dependence of the total heat transfer coefficient, which reflects the processes of heat transfer by convection and radiation, is borrowed from [6]. Accounting for nonlinearity in the boundary conditions is due to the fact that, unlike other thermophysical parameters, the coefficient is most sensitive to temperature changes and its value can vary within very wide limits [7].

At the collision site and at the interfaces between the layers there is an ideal thermal contact location:

$$
[\mathrm{T}]=\left[\mathrm{K} \frac{\partial \mathrm{T}}{\partial z}\right]=0
$$

At the moment of time $t=0$ the colliding bodies are free from stresses, and for the impactor the initial velocities of the translational and rotational motions are given:

$$
\vartheta(r, z)=V_{0}, w(r, z)=w_{0} r\left(r_{0} \leq r \leq R,-h_{0} \leq z \leq 0\right) .
$$

The initial temperatures of the striker and the obstacle are respectively equal to $\mathrm{T}^{*}$ and $\mathrm{T}_{*}$

Note that in the contact interaction of solids, where the fast wave process is usually considered up to $10^{-5}-10^{-3} C$, the temperature field initiated only by dynamic mechanical effects, can be calculated in the adiabatic approximation. Boundary and initial conditions for temperature are necessary only in the cooling problem, when the heated cylinder comes in contact with the surface of the plate and the calculation of their thermal state is carried out over rather long time intervals.

For the numerical solution of the mixed boundary-value problem (1)-(8), we construct an explicit difference scheme based on the grid-characteristic approach and the principle of the electrothermal analogy. The expediency of using an explicit scheme is due to the fact that implicit schemes have a lower resolution when calculating transient processes in deformable media. Implicit counting, as a rule, does not impose restrictions on the size of the time step, since in the overwhelming majority they are absolutely stable. However, the region of dependence of difference equations for them is greatly expanded, as a result of which the profiles of wave fronts are substantially smoothed out and the whole picture of unsteady wave motion turns out to be blurred. Moreover, the algorithms of implicit schemes are much more complicated and their implementation requires much more computational resources.

The domain of applicability of implicit schemes seems to be limited to the class of steady motions, when time plays a purely auxiliary role in the calculations. In addition, in some problems, some countable regions can be calculated using implicit schemes, while others can be calculated using explicit ones.

The construction of a difference scheme begins with the construction of a difference grid, according to which the calculation will be carried out. For this, the area of change of continuous arguments $r$ is divided into rectangular cells with sides $h_{r i}$ and $h_{z j}(i=1,2, \ldots, I ; j=1,2, \ldots, J)$, each cell is assigned a number $\left(i-\frac{1}{2}, j-\frac{1}{2}\right)$. The calculation is carried out by successive steps in time. The values of the desired functions on the time layer $(n+1) \tau$ are determined at fixed grid nodes corresponding to the geometric center of the cells, but by known solution on the previous layer $n \tau$.

Using the central differences for the approximation of the first derivatives but spatial variables, we replace the hyperbolic equations of the system (1) with their finite-difference analogues: 


$$
\begin{aligned}
& u_{i-\frac{1}{2}, j-\frac{1}{2}}^{n+1}=u_{i-\frac{1}{2}, j-\frac{1}{2}}^{n}+ \\
& +\frac{\tau}{\rho_{i-\frac{1}{2}, j-\frac{1}{2}}}\left[\frac{\left(\sum_{r i, j-\frac{1}{2}}^{n+\frac{1}{2}}-\sum_{r i-1, j-\frac{1}{2}}^{n+\frac{1}{2}}\right)}{h_{r i}}+\frac{\left(\sum_{r z i-\frac{1}{2}, j}^{n+\frac{1}{2}}-\sum_{r z i-\frac{1}{2}, j-1}^{n+\frac{1}{2}}\right)}{h_{z j}}+\frac{\left(\sigma_{r i-\frac{1}{2}, j-\frac{1}{2}}^{n}-\sigma_{\varphi i-\frac{1}{2}, j-\frac{1}{2}}^{n}\right)}{r_{i-\frac{1}{2}}}\right] \text {; } \\
& \vartheta_{i-\frac{1}{2}, j-\frac{1}{2}}^{n+1}=\vartheta_{i-\frac{1}{2}, j-\frac{1}{2}}^{n}+ \\
& +\frac{\tau}{\rho_{i-\frac{1}{2}, j-\frac{1}{2}}}\left[\frac{\left(\sum_{r z i, j-\frac{1}{2}}^{n+\frac{1}{2}}-\sum_{r z i-1, j-\frac{1}{2}}^{n+\frac{1}{2}}\right)}{h_{r i}}+\frac{\left(\sum_{z i-\frac{1}{2}, j}^{n+\frac{1}{2}}-\sum_{z i-\frac{1}{2}, j-1}^{n+\frac{1}{2}}\right)}{h_{z j}}+\frac{\sigma_{r z i-\frac{1}{2}, j-\frac{1}{2}}^{n}}{r_{i-\frac{1}{2}}}\right] ; \\
& \omega_{i-\frac{1}{2}, j-\frac{1}{2}}^{n+1}=\omega_{i-\frac{1}{2}, j-\frac{1}{2}}^{n}+ \\
& +\frac{\tau}{\rho_{i-\frac{1}{2}, j-\frac{1}{2}}}\left[\frac{\left(\sum_{r \varphi i, j-\frac{1}{2}}^{n+\frac{1}{2}}-\sum_{r \varphi i-1, j-\frac{1}{2}}^{n+\frac{1}{2}}\right)}{h_{r i}}+\frac{\left(\sum_{z \varphi i-\frac{1}{2}, j}^{n+\frac{1}{2}}-\sum_{z \varphi i-\frac{1}{2}, j-1}^{n+\frac{1}{2}}\right)}{h_{z j}}+\frac{2 \sigma_{r \varphi i-\frac{1}{2}, j-\frac{1}{2}}^{n}}{r_{i-\frac{1}{2}}}\right] \text {; } \\
& \begin{array}{c}
\sigma_{r i-\frac{1}{2}, j-\frac{1}{2}}^{n+1}=\left(1-\tau \eta_{i-\frac{1}{2}, j-\frac{1}{2}}\right) \cdot \sigma_{r i-\frac{1}{2}, j-\frac{1}{2}}^{n}+\tau \beta_{i-\frac{1}{2}, j-\frac{1}{2}} \sigma_{i-\frac{1}{2}, j-\frac{1}{2}}^{n}+ \\
+\tau\left[\frac{\left(\lambda_{i-\frac{1}{2}, j-\frac{1}{2}}+2 \mu_{i-\frac{1}{2}, j-\frac{1}{2}}\right) \cdot\left(U_{i, j-\frac{1}{2}}^{n+\frac{1}{2}}-U_{i-1, j-\frac{1}{2}}^{n+\frac{1}{2}}\right)}{h_{r i}}+\lambda_{i-\frac{1}{2}, j-\frac{1}{2}}\left(\frac{\left(\begin{array}{c}
V_{i-\frac{1}{2}, j}^{n+\frac{1}{2}}-V_{i-\frac{1}{2}, j-1}^{n+\frac{1}{2}} \\
h_{z j}
\end{array}\right)}{h_{i-\frac{1}{2}, j-\frac{1}{2}}} r_{i-\frac{1}{2}}\right)\right]-
\end{array} \\
& -p_{i-\frac{1}{2}, j-\frac{1}{2}} \cdot\left(\mathrm{T}_{i-\frac{1}{2}, j-\frac{1}{2}}^{n+1}-\mathrm{T}_{i-\frac{1}{2}, j-\frac{1}{2}}^{n}\right) \text {; } \\
& \sigma_{\varphi i-\frac{1}{2}, j-\frac{1}{2}}^{n+1}=\left(1-\tau \eta_{i-\frac{1}{2}, j-\frac{1}{2}}\right) \cdot \sigma_{\varphi i-\frac{1}{2}, j-\frac{1}{2}}^{n}+\tau \beta_{i-\frac{1}{2}, j-\frac{1}{2}} \sigma_{i-\frac{1}{2}, j-\frac{1}{2}}^{n}+
\end{aligned}
$$

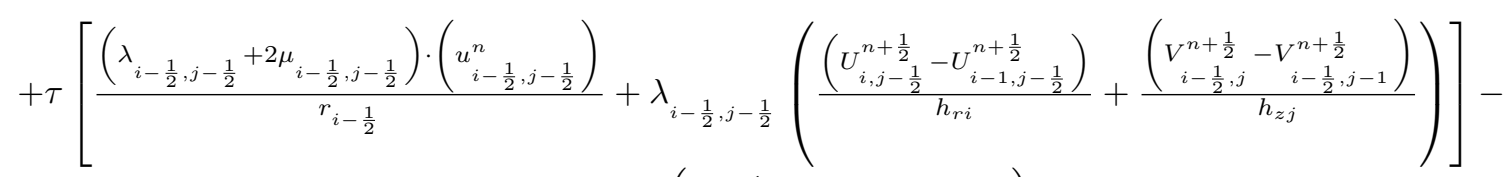

$$
\begin{aligned}
& -p_{i-\frac{1}{2}, j-\frac{1}{2}} \cdot\left(\mathrm{T}_{i-\frac{1}{2}, j-\frac{1}{2}}^{n+1}-\mathrm{T}_{i-\frac{1}{2}, j-\frac{1}{2}}^{n}\right) \text {; } \\
& \sigma_{z i-\frac{1}{2}, j-\frac{1}{2}}^{n+1}=\left(1-\tau \eta_{i-\frac{1}{2}, j-\frac{1}{2}}\right) \cdot \sigma_{z i-\frac{1}{2}, j-\frac{1}{2}}^{n}+\tau \beta_{i-\frac{1}{2}, j-\frac{1}{2}} \sigma_{i-\frac{1}{2}, j-\frac{1}{2}}^{n}+ \\
& +\tau\left[\frac{\left(\lambda_{i-\frac{1}{2}, j-\frac{1}{2}}+2 \mu_{i-\frac{1}{2}, j-\frac{1}{2}}\right) \cdot\left(V_{i-\frac{1}{2}, j}^{n+\frac{1}{2}}-V_{i-\frac{1}{2}, j-1}^{n+\frac{1}{2}}\right)}{h_{z j}}+\lambda_{i-\frac{1}{2}, j-\frac{1}{2}}\left(\frac{\left(U_{i, j-\frac{1}{2}}^{n+\frac{1}{2}}-U_{i-1, j-\frac{1}{2}}^{n+\frac{1}{2}}\right)}{h_{r i}}+\frac{\left(u_{i-\frac{1}{2}, j-\frac{1}{2}}^{n}\right)}{r_{i-\frac{1}{2}}}\right)\right]- \\
& -p_{i-\frac{1}{2}, j-\frac{1}{2}} \cdot\left(\mathrm{T}_{i-\frac{1}{2}, j-\frac{1}{2}}^{n+1}-\mathrm{T}_{i-\frac{1}{2}, j-\frac{1}{2}}^{n}\right) \text {; } \\
& \sigma_{r \varphi i-\frac{1}{2}, j-\frac{1}{2}}^{n+1}=\left(1-\tau \eta_{i-\frac{1}{2}, j-\frac{1}{2}}\right) \cdot \sigma_{r \varphi-\frac{1}{2}, j-\frac{1}{2}}^{n}+\tau \mu_{i-\frac{1}{2}, j-\frac{1}{2}}\left(\left(\frac{\left(W_{i, j-\frac{1}{2}}^{n+\frac{1}{2}}-W_{i-1, j-\frac{1}{2}}^{n+\frac{1}{2}}\right)}{h_{r i}}+\frac{\left(w_{i-\frac{1}{2}, j-\frac{1}{2}}^{n}\right)}{r_{i-\frac{1}{2}}}\right)\right) \\
& \sigma_{z \varphi i-\frac{1}{2}, j-\frac{1}{2}}^{n+1}=\left(1-\tau \eta_{i-\frac{1}{2}, j-\frac{1}{2}}\right) \cdot \sigma_{z \varphi-\frac{1}{2}, j-\frac{1}{2}}^{n}+\tau \mu_{i-\frac{1}{2}, j-\frac{1}{2}} \frac{\left(W_{i, j-\frac{1}{2}}^{n+\frac{1}{2}}-W_{i-1, j-\frac{1}{2}}^{n+\frac{1}{2}}\right)}{h_{z j}} \\
& \left.\sigma_{r z i-\frac{1}{2}, j-\frac{1}{2}}^{n+1}=\left(1-\tau \eta_{i-\frac{1}{2}, j-\frac{1}{2}}\right) \cdot \sigma_{r z i-\frac{1}{2}, j-\frac{1}{2}}^{n}+\tau \mu_{i-\frac{1}{2}, j-\frac{1}{2}}\left(\frac{\left(\begin{array}{c}
U_{i-\frac{1}{2}, j}^{n+\frac{1}{2}}-U_{i-\frac{1}{2}, j-1}^{n+\frac{1}{2}} \\
h_{z j}
\end{array}\right)}{h_{i, j-\frac{1}{2}}-V_{i-1, j-\frac{1}{2}}^{n+\frac{1}{2}}}\right)\right)
\end{aligned}
$$


In the two-layer difference scheme (9), the auxiliary «large» quantities U, V, W, Z, defined at the points of the boundaries of the rectangular cells, are calculated using coordinate wise splitting of the spatial two-dimensional equations (1) and using one-dimensional relations on the characteristics [8].

After obvious transformations, the difference scheme for the heat equation takes the form

$$
\begin{gathered}
\frac{C_{i-\frac{1}{2}, j-\frac{1}{2}}\left(\mathrm{~T}_{i-\frac{1}{2}, j-\frac{1}{2}}^{n+1}-\mathrm{T}_{i-\frac{1}{2}, j-\frac{1}{2}}^{n}\right)}{\tau}= \\
=-\mathrm{T}_{i-\frac{1}{2}, j-\frac{1}{2}}^{n} \cdot p_{i-\frac{1}{2}, j-\frac{1}{2}}\left[\frac{\left(U_{i, j-\frac{1}{2}}^{n+\frac{1}{2}}-U_{i-1, j-\frac{1}{2}}^{n+\frac{1}{2}}\right)}{h_{r i}}+\frac{\left(V_{i-\frac{1}{2}, j}^{n+\frac{1}{2}}-V_{i-\frac{1}{2}, j-1}^{n+\frac{1}{2}}\right)}{h_{z j}}+\frac{\left(u_{i-\frac{1}{2}, j-\frac{1}{2}}^{n}\right)}{r_{i-\frac{1}{2}}}\right]+\frac{1}{d_{i-\frac{1}{2}, j-\frac{1}{2}}} \times \\
\times\left(\alpha_{r i-\frac{1}{2}, j-\frac{1}{2}}^{-} \mathrm{T}_{i-\frac{3}{2}, j-\frac{1}{2}}^{n}+\alpha_{r i-\frac{1}{2}, j-\frac{1}{2}}^{+} \mathrm{T}_{i+\frac{1}{2}, j-\frac{1}{2}}^{n}+\mathrm{T}_{z i-\frac{1}{2}, j-\frac{1}{2}} \mathrm{~T}_{i-\frac{1}{2}, j-\frac{3}{2}}^{n}+\alpha_{z i-\frac{1}{2}, j-\frac{1}{2}}^{+} \mathrm{T}_{i-\frac{1}{2}, j+\frac{1}{2}}^{n}-\gamma_{i-\frac{1}{2}, j-\frac{1}{2}} \mathrm{~T}_{i-\frac{1}{2}, j-\frac{1}{2}}^{n}\right)+W_{i-\frac{1}{2}, j-\frac{1}{2}}^{*^{n}} \\
\left(\gamma_{i-\frac{1}{2}, j-\frac{1}{2}}=\alpha_{r i-\frac{1}{2}, j-\frac{1}{2}}^{-}+\alpha_{r i-\frac{1}{2}, j-\frac{1}{2}}^{+}+\alpha_{z i-\frac{1}{2}, j-\frac{1}{2}}^{-}+\alpha_{z i-\frac{1}{2}, j-\frac{1}{2}}^{+}\right) .
\end{gathered}
$$

Here $\gamma_{i-\frac{1}{2}, j-\frac{1}{2}}$ is the total thermal conductivity of the cell.

In proving the stability of the difference scheme from the initial data, we first consider the uncoupled viscoelastic problem without taking into account temperature additions $\frac{p \partial \mathrm{T}}{\partial t}$ in the relationship between normal stresses and strains.

A two-layer difference scheme (9) corresponds to a transition operator $H$, that translates a solution vector $\vec{F}$ on a temporary layer $t_{n}=n \tau$ into a vector $\vec{F}_{1}$ on a layer $t_{n+1}=t_{n}+\tau$

$$
\vec{F}_{1}=H \vec{F}
$$

The scheme is stable on the initial data, if the condition is met

$$
\|\mathrm{H}\| \leq 1
$$

The operator norm is determined by the energy norm of the vector $\vec{F}$ :

$$
\|\vec{F}\|^{2}=\mathrm{K}(t)+\mathrm{P}(t),\|\mathrm{H}\|=\sup \|\mathrm{H} \vec{F}\|,\|\vec{F}\|=1,
$$

where

$$
\begin{gathered}
\mathrm{K}(t)=\frac{1}{2} \sum_{i=1}^{I} \sum_{j=1}^{J} \rho_{i-\frac{1}{2}, j-\frac{1}{2}}\left(u_{i-\frac{1}{2}, j-\frac{1}{2}}^{2}+v_{i-\frac{1}{2}, j-\frac{1}{2}}^{2}+w_{i-\frac{1}{2}, j-\frac{1}{2}}^{2}\right) \cdot h_{r i} \cdot h_{z j} ; \\
\mathrm{P}(t)=\frac{1}{2}(\vec{\sigma}, \vec{\varepsilon})=\frac{1}{2}\left(\sigma_{r} \varepsilon_{r}+\sigma_{\varphi} \varepsilon_{\varphi}+\sigma_{z} \varepsilon_{z}+\sigma_{r \varphi} \varepsilon_{r \varphi}+\sigma_{z \varphi} \varepsilon_{z \varphi}+\sigma_{r z} \varepsilon_{r z}\right)= \\
=\frac{1}{2} \sum_{i=1}^{I} \sum_{j=1}^{J}\left\{\alpha \sigma_{r}^{2}+2 q \sigma_{r} \sigma_{z}+\alpha \sigma_{z}^{2}+\frac{1}{\mu}\left[\sigma_{r \varphi}^{2}+\sigma_{z \varphi}^{2}+\sigma_{r z}^{2}\right]+\frac{1}{\mathrm{E}}\left[\sigma_{\varphi}-\nu\left(\sigma_{r}+\sigma_{z}\right)\right]^{2}\right\}_{i-\frac{1}{2}, j-\frac{1}{2}} \times \\
\quad \times h_{r i} \cdot h_{z j} ; \\
\alpha=\frac{a^{2}}{4 \rho b^{2}\left(a^{2}-b^{2}\right)} ; q=\frac{2 b^{2}-a^{2}}{4 \rho b^{2}\left(a^{2}-b^{2}\right)} ; \mathrm{E}=\frac{\alpha-2 q}{(q-\alpha)^{2}} ; \nu=\frac{q}{q-\alpha} .
\end{gathered}
$$

Here $\mathrm{K}(t)$ and $\mathrm{P}(t)$ up to a constant factor corresponds to a discrete analogue of kinetic and potential energy.

Equality (13) can be written in matrix form:

$$
\|\vec{F}\|_{\mathrm{A}}^{2}=\frac{1}{2}(\mathrm{~A} \vec{F}, \vec{F}),
$$


where the scalar product is defined as follows:

$$
(\vec{F}, \vec{W})=\sum_{i=1}^{I} \sum_{j=1}^{J}\left(\sum_{k=1}^{g} F_{k, i-\frac{1}{2}, j-\frac{1}{2}} W_{k, i-\frac{1}{2}, j-\frac{1}{2}}\right) \cdot h_{r i} \cdot h_{z j},
$$

and a positive definite matrix $\mathrm{A}$ has the form

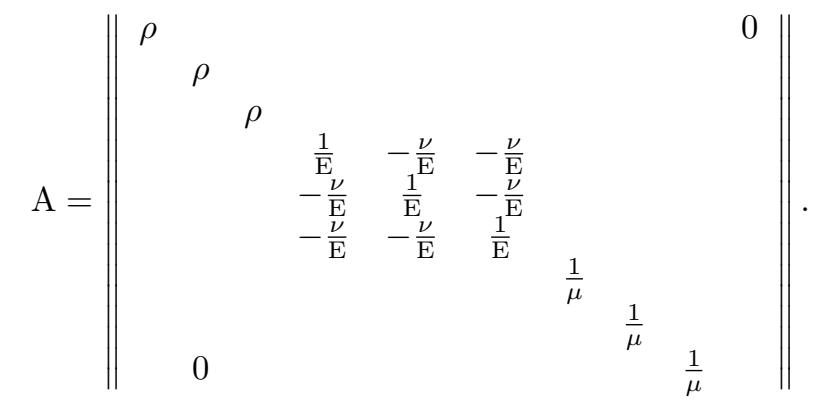

From (11), (12) we have

$$
\left\|\vec{F}\left(t_{n+1}\right)\right\|_{\mathrm{A}}=\left\|\mathrm{H} \vec{F}\left(t_{n}\right)\right\|_{\mathrm{A}} \leq\|\mathrm{H}\|_{\mathrm{A}}\left\|\vec{F}\left(t_{n}\right)\right\|_{\mathrm{A}} \leq\left\|\vec{F}\left(t_{n}\right)\right\|_{\mathrm{A}} \leq\left\|\vec{F}\left(t_{n-1}\right)\right\|_{\mathrm{A}} \leq \ldots \leq\left\|\vec{F}\left(t_{1}\right)\right\|_{\mathrm{A}} \leq\|\vec{F}(0)\|_{\mathrm{A}},
$$

which means the stability of the scheme according to the initial data.

The operator $\mathrm{H}$ can be represented as

$$
\mathrm{H}=I+\tau\left(\mathrm{H}_{r}+\mathrm{H}_{z}+\mathrm{H}_{\mathrm{B}}\right)=\left(1-\frac{\tau}{\tau_{r}}-\frac{\tau}{\tau_{z}}-\frac{\tau}{\tau_{\mathrm{B}}}\right) \cdot I+\frac{\tau}{\tau_{r}}\left(I+\tau_{r} \mathrm{H}_{r}\right)+\frac{\tau}{\tau_{z}}\left(I+\tau_{z} \mathrm{H}_{z}\right)+\frac{\tau}{\tau_{\mathrm{B}}}\left(I+\tau_{\mathrm{B}} \mathrm{H}_{\mathrm{B}}\right) .
$$

Here $I$ is the identity operator; $\mathrm{H}_{r}, \mathrm{H}_{z}$ are operators containing differential derivatives only with respect to spatial variables $r$ and $z$, respectively; $\tau_{r}, \tau_{z}$ are time steps of «one-dimensional» schemes, corresponding to the operator $I+\tau_{r} \mathrm{H}_{r}$ and $I+\tau_{z} \mathrm{H}_{z}\left(\tau_{r}>0, \tau_{z}>0\right)$; the matrix of coefficients, taking into account viscous properties of the medium,

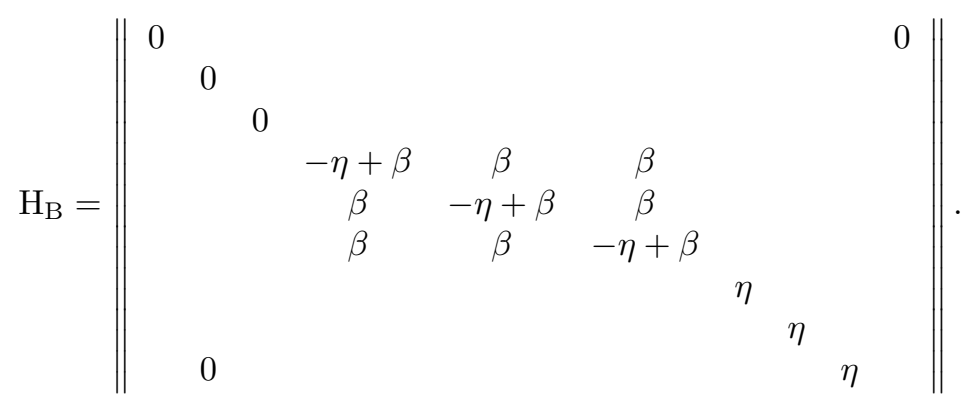

As by defining the norm

$$
\|\mathrm{H}\|_{\mathrm{A}} \leq\left|1-\frac{\tau}{\tau_{r}}-\frac{\tau}{\tau_{z}}-\frac{\tau}{\tau_{\mathrm{B}}}\right|\|I\|_{\mathrm{A}}+\frac{\tau}{\tau_{r}}\left\|I+\tau_{r} \mathrm{H}_{r}\right\|_{\mathrm{A}}+\frac{\tau}{\tau_{r}}\left\|I+\tau_{z} \mathrm{H}_{z}\right\|_{\mathrm{A}}+\frac{\tau}{\tau_{\mathrm{B}}}\left\|I+\tau_{\mathrm{B}} \mathrm{H}_{\mathrm{B}}\right\|_{\mathrm{A}},
$$

then for the stability of the scheme specified by the operator $\mathrm{H}$, it is enough to choose a step $\tau$ based on the condition

$$
1-\frac{\tau}{\tau_{r}}-\frac{\tau}{\tau_{z}}-\frac{\tau}{\tau_{\mathrm{B}}} \geq 0
$$

if at the same time the steps $\tau_{r}, \tau_{z}, \tau_{\mathrm{B}}$ ensure the implementation of inequalities

$$
\left\|I+\tau_{r} \mathrm{H}_{r}\right\|_{\mathrm{A}} \leq 1,\left\|I+\tau_{z} \mathrm{H}_{z}\right\|_{\mathrm{A}} \leq 1,\left\|I+\tau_{\mathrm{B}} \mathrm{H}_{\mathrm{B}}\right\|_{\mathrm{A}} \leq 1
$$

Let's consider the last inequality in (15), in which the matrix $I+\tau_{\mathrm{B}} \mathrm{H}_{\mathrm{B}}$ defines the difference scheme

$$
\frac{\vec{F}_{1}-\vec{F}}{\tau_{\mathrm{B}}}=\mathrm{H}_{\mathrm{B}} \vec{F} \quad 8 ; 8 \quad \vec{F}_{1}=\left(I+\tau_{\mathrm{B}} \mathrm{H}_{\mathrm{B}}\right) \cdot \vec{F} .
$$


It is known from the properties of the norm of the matrix that

$$
\left\|I+\tau_{\mathrm{B}} \mathrm{H}_{\mathrm{B}}\right\|_{\mathrm{A}} \leq \lambda_{m},
$$

where $\lambda_{m}$ - the maximum modulo eigenvalue of the matrix $I+\tau_{\mathrm{B}} \mathrm{H}_{\mathrm{B}}$. Therefore, to satisfy the inequality in question, it suffices to require meeting conditions

$$
\left|1+\tau_{\mathrm{B}} \eta\right| \leq 1 ;\left|1+\tau_{\mathrm{B}}(\beta-\eta)\right| \leq 1,
$$

of which we have

$$
\tau_{\mathrm{B}} \leq \min \left\{\frac{2}{\eta}, \frac{2}{\beta-\eta}\right\}
$$

Since the parameters $\eta, \beta$ depend on the indices $i, j$ and $\eta \geq \beta \geq 0$, then, denoting $\eta_{m}=\max _{i, j} \eta_{i-\frac{1}{2}, j-\frac{1}{2}}$, we get $\tau_{\mathrm{B}} \leq \frac{2}{\eta_{m}}$.

Then, based on the constraint (14) for the stability of a two-dimensional scheme with respect to the initial data, it suffices that the size of the time step satisfies the inequality

$$
\tau\left(\frac{1}{\tau_{r}}+\frac{1}{\tau_{z}}+\frac{\eta_{m}}{2}\right) \leq 1
$$

where

$$
\tau_{r}=\min _{i, j} \frac{h_{r i}}{a_{i-\frac{1}{2}, j-\frac{1}{2}}}, \tau_{z}=\min _{i, j} \frac{h_{z j}}{a_{i-\frac{1}{2}, j-\frac{1}{2}}} .
$$

Thus, the stability of the proposed difference scheme (9), further in accordance with the theory of A.A. Samarskii [9], the convergence of the solution of the difference scheme (9) to the solution of the differential problem (1), (2) is obtained.

\section{References}

1 Победря Б.Е. О связанных задачах в механике сплошной среды / Б.Е. Победря // Упругость и неупругость: сб. науч. тр. - Вып. 2. - М.: Изд-во ЛГУ, 1971. - С. 224-253.

2 Горский Н.M. О решении динамических задач теории упругости в напряжениях и скоростях смещений / Н.М. Горский / Численные методы механики сплошной среды. - Т. 3, № 3. - Новосибирск: ВЦ СО АН СССР, 1972. - С. 32-41.

3 Горский Н.М., Коновалов А.Н. О разностных методах решения динамических задач теории упругости: труды III Всесоюз. конф. по численным методам решения задач теории упругости и пластичности. - Т. І. - Новосибирск: ВЦ СО АН СССР, 1974. - С. 68-84.

4 Clifton K.I. A difference method for plane problems in dynamic elasticity / K.I. Clifton. - Juart. Appl. Math. - 1967. - Vol. 25. - N 1. - P. 97-116.

5 Боли Б. Теория температурных напряжений / Б. Боли, Дж. Уэйнер. - М.: Мир, 1964. - 517 с.

6 Дульнев Г.Н. Теплообмен в радиоэлектронных аппаратах / Г.Н. Дульнев, Э.М. Семяшкин. - Л.: Энергия, 1968. - 360 с.

7 Коваленко А.Д. Термоупругость / А.Д. Коваленко. - Киев: Выща шк., 1975. - 216 с.

8 Годунов С.К. Численное решение многомерных задач газовой динамики / С.К. Годунов, А.В. Забродин, М.Я. Иванов и др. - М.: Наука, 1976. - 400 с.

9 Самарский А.А. Теория разностных схем: учеб. пос. / А.А. Самарский. - М.: Наука, 1977. - 658 с. 
М.М. Букенов, А.А. Адамов, Е.М. Мухаметов

\title{
Қабатты ортадағы екіөлшемді термотұтқырсерпімді толқындар
}

\begin{abstract}
Қатты дененің деформациясының динамикалық мәселелері ТМД және шетелдерде көптеген зерттеулердің тақырыбы болды. Аталған және басқа жарияланған жұмыстарда қабылданған жорамалдарды жеңілдету, соқтығу мен кедергі сияқты, кинематика мен кернеу жағдайын сипаттайтын механикалық және математикалық модельдерді одан әрі жетілдіру мен жақсарту қажеттілігіне әкеледі. Сонымен қатар термотұтқырсерпімді теориясының шеңберінде еркін қуыстар мен қатаң кірмелерді қамтитын изотроптық пластиналар түрінде кедергі бар цилиндрлік индетанттың осьтік симметриялық соқтығы сандық түрде зерттелді. Серпімділік теориясының және қысымның икемділігі туралы теориялық есептердің әртүрлі тұжырымдамалары болуы мүмкін. Дегенмен, жылдамдық пен кернеулерде пайдаланылатын формулалар әмбебап болып табылады, себебі ол негізгі шекаралық шарттарды (аралас шарттарды қоса) біркелкі түрде шешуге мүмкіндік туғызады. Бұл жұмыста тор-сипаттамалық схема және оның конвергенциясы берілген. А.А. Самарскийдің теориясына сәйкес, тор есебі арқылы энергетикалық нормадағы орнықтылығы дәлелденген.
\end{abstract}

Kiлm сөздер: екіөлшемді термотұтқырсерпімді толқындар, айырымдық схеманың орнықтылығы, айырымдық есептің шешімінің жинақтылығы, индентор, деформация, тензор, кернеу.

\author{
М.М. Букенов, А.А. Адамов, Е.М. Мухаметов \\ Двумерные термовязкоупругие волны \\ в слоистых средах
}

\begin{abstract}
Динамические задачи о деформировании твердых тел явились предметом многочисленных исследований в СНГ и за рубежом. Отказ от ряда упрощающих предположений, принятых в цитируемых и других опубликованных работах, приводит к необходимости дальнейшего уточнения и совершенствования механико-математических моделей, описывающих кинематику и напряженное состояние как ударника, так и преграды. Далее в рамках связанной теории термовязкоупругости численно исследовано осесимметричное соударение цилиндрического индентора с препятствием в виде пакета изотропных пластин, содержащего свободные полости и жесткие включения. Возможны различные формулировки задач теории упругости и термовязкоупругости. Однако используемая постановка в скоростях и напряжениях является одной из наиболее универсальных, так как позволяет решать основные граничные задачи (в том числе и смешанные) единообразным способом. В работе даны сеточно-характеристическая схема и ее сходимость. В соответствии с теорией А.А. Самарского, доказана устойчивость в энергетической норме сеточной задачи.
\end{abstract}

Ключевые слова: двумерные термовязкоупругие волны, устойчивость разностной схемы, сходимость решения разностной задачи, индентор, деформация, тензор, напряжения.

\section{References}

1 Pobedria, B.E. (1971). O sviazannykh zadachakh v mekhanike sploshnoi sredy [On related problems in continuum mechanics]. Upruhost $i$ neupruhost - Elasticity and inelasticity, Issue 2, 224-253. Moscow: Izdatelstvo LHU[in Russian].

2 Gorskii, N.M. (1972). O reshenii dinamicheskikh zadach teorii upruhosti v napriazheniiakh i skorostiakh smeshchenii [On the solution of dynamic problems of the theory of elasticity in stresses and velocities of displacements]. Chislennye metody mekhaniki sploshnoi sredy - Numerical method in continuum mechanics, Vol. 3, 3, 32-41. Novosibirsk: VTs SO AN SSSR [in Russian]. 
3 Gorskii, N.M., \& Konovalov, A.N. (1974). O raznostnykh metodakh resheniia dinamicheskikh zadach teorii upruhosti [Differential method of solving dynamic problems of elasticity theory]. Trudy III Vsesoiuznoi konferentsii po chislennym metodam resheniia zadach teorii upruhosti i plastichnosti - Proceeding of III Allunion conference on numerical metods in elasticity and plastic theory, 1, 68-84. Novosibirsk: VTs SO AN SSSR [in Russian].

4 Clifton, K.I. (1967) A difference method for plane problems in dynamic elasticity. Juart. Appl. Math., Vol. 25, 1, 97-116.

5 Boli, B., \& Ueiner, Dzh. (1960). Teoriia temperaturnykh napriazhenii [Theory of Thermal Stresses]. Moscow: Mir [in Russian].

6 Dulnev, G.N., \& Semiashkin, E.M. (1968). Teploobmen v radioelektronnykh apparatakh /Heat transfer in electronic devices]. Leningrad: Enerhia [in Russian].

7 Kovalenko, A.D. (1975). Termoupruhost [Thermoelasticity]. Kiev: Vishzha shkola [in Russian].

8 Goduno,v S.K., Zabrodin, A.V., Ivanov, M.Ia. \& et al. (1976). Chislennoe reshenie mnohomernykh zadach hazovoi dinamiki [Computational solution of multidimensional gas dynamics problems]. Moscow: Nauka [in Russian].

9 Samarskii, A.A. (1977). Teoriia raznostnykh skhem [The Theory of difference scheme]. Moscow: Nauka [in Russian]. 